\title{
Plant production-community composition relationship associated with fungal guilds depends on grassland disturbance in surface and subsurface soils
}

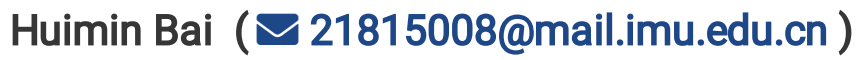

Inner Mongolia University https://orcid.org/0000-0001-9517-1037

Zhiying Liu

Inner Mongolia University https://orcid.org/0000-0002-5483-6132

Huizhen Li

Inner Mongolia University

Tianqi Wang

Inner Mongolia University

Hongbin Xu

Inner Mongolia University

Tianyu Zhang

Inner Mongolia University

Taogetao Baoyin

Inner Mongolia University

\section{Research Article}

Keywords: fungal functional guilds, plant production, community composition, grassland disturbances, typical steppe

Posted Date: October 18th, 2021

DOI: https://doi.org/10.21203/rs.3.rs-944092/v1

License: (c) (i) This work is licensed under a Creative Commons Attribution 4.0 International License. Read Full License 


\section{Abstract \\ Purpose}

Soil fungal guilds have been proven to influence the plant community composition-production relationship, but not much is known about their effects on surface and subsurface soils under different disturbances.

\section{Methods}

Here, we assessed the functional characteristics of three fungal groups using the Ribosomal Database Project (RDP) classifier and data available in FUNGuild, and we characterized the community of saprotrophic, mycorrhizal, and potential plant pathogenic fungi in surface $(0-10 \mathrm{~cm})$ and subsurface soils $(10-20 \mathrm{~cm})$ of temperate grasslands under different management practices.

\section{Results}

We found that grassland disturbances decreased plant aboveground production and changed plant community composition. In surface soil, antagonistic interaction between potential plant pathogens and saprotrophic fungi drove the plant community composition-production relationship. In subsurface soil, this relationship was driven by antagonistic interaction between mycorrhizal fungi and potential plant pathogens.

\section{Conclusion}

These findings revealed that under grassland disturbances, the surface soil fungal communities were more strongly associated with plant community composition-production relationship than those from the subsurface soil were. Potential plant pathogens played an important role in plant community composition-production relationship. This knowledge is important for predicting the shifts in ecosystem functions as a consequence of changes in soil fungal groups during grassland management.

\section{Introduction}

Grazing and mowing are the main ways of human disturbance to grassland ecosystems (Gong et al. 2014), and they are the main grassland management strategies in China (Liu et al. 2018). The grazing intensity increases, the habitat, and productivity of the grassland ecosystem show a significant downward trend, reducing biodiversity (Eldridge \& Delgado-Baquerizo 2017). Mowing significantly changes the species richness of aboveground plants (DÍAz et al. 2007), increasing plant community stability (Yang et al. 2012). Selective grazing, trampling and return of nitrogen from livestock in grazing areas cause habitat heterogeneity, while uniform harvesting in mowing areas highly affects species 
communities causing habitat homogeneity (Fóti et al. 2017; Chisté et al. 2018). Appropriate disturbance levels tend to promote grass growth, maintain stable plant community composition and productivity, and increase heterotrophic microbial activity (Hamilton \& Frank 2001; Schönbach et al. 2011); however, excessive disturbance reduces the complexity of plant community composition and decreases soil microbial community diversity and plant productivity (Bardgett et al. 1998; Schönbach et al. 2011). Thus, grassland disturbance affects both plant community composition-production relationships and subsurface microbial communities (Vannucchi et al. 2015; Frąc et al. 2018). Thus, when evaluating the versatility of sustainable grassland ecosystem management, both above- and below-ground biodiversity must be considered (Putten et al. 2016; Wang et al. 2020b).

Grassland disturbances (grazing and mowing) influence the soil microenvironment, causing changes in the soil nutrient availability and significantly affecting the fungal community structure and soil fungal activity (Ingram et al. 2008; Józefowska et al. 2018; Xun et al. 2018). These disturbances also change the interactions between fungal guilds (Grau et al. 2017), reduce grassland carbon sequestration, and cause changes in grassland production, diversity, and their potential relationships. However, Chen et al. (2018) reported that soil fungal diversity regulated the plant community composition-production relationship, and that it was not consistent in surface and subsurface soil. In semi-arid grasslands, exogenous nutrient addition induces soil environment and plant community changes, and plays a major role in shaping fungal diversity in surface soil. Conversely, in subsurface soil, fungal diversity is primarily controlled by exogenous nutrient addition and changes in plant community attributes (i.e., aboveground plant production and plant community composition). However, it is unknown how various disturbances that alter aboveground grassland structure impact the community assembly, abundance, and diversity of soil fungi, which have wide-ranging effects on grassland health, biogeochemistry, and regeneration (Liu et al. 2015; Tardy et al. 2015).

Fungal functional guilds play an important role in driving soil processes and can be used to predict soil abiotic factors and plant community characteristics (Chen et al. 2020). Many studies have shown that plant community composition-production relationships are controlled by complex networks of plants, soil, and microorganisms (Yang et al. 2015; Lozano et al. 2017); this relationship can also be influenced by a series of biotic and abiotic factors (Guo et al. 2019). In greenhouse experiments, Yang et al. (2015) found that the strong effects of soil biota in soils do not simply accrue in experimental monocultures, but can occur in low diversity assemblages which are more realistic representations of what occurs in nature, as they contribute to spatial and temporal patterns of abundance in natural plant communities through negative plant-soil feedback. Fungi play important roles in the ecosystem through interactions of saprophytic fungi, mycorrhizal fungi, and potential plant pathogen fungi; these relationships are the determinants of the close relationship between plant community composition and production in terrestrial ecosystems (Heijden et al. 2008; Schnitzer et al. 2011). For example, potential plant pathogens can contribute to the maintenance of plant diversity by specifically suppressing dominant plants (Schnitzer et al. 2011). The results of the study by Yang et al. (2018) highlighted the importance of arbuscular mycorrhizal fungi (AMF) in structuring natural above-ground production under various biodiversity loss scenarios, and indicated that AMF will be able to modify vegetation dynamics in 
response to the future plant diversity loss. Saprophytic fungi play a role in plant decomposition. Previous studies have examined how individual disturbances impact the community composition of soil fungi in grasslands. For example, grazing led to a significant decrease in fungal species diversity and abundance of pathotrophs, saprotrophs, and symbiotrophs (Yin et al. 2019). Long-term destocking can be considered as an important predictor of fungal functional guilds, and changes in these microorganisms were associated with grazing cessation-induced shifts in plants and soil (Wang et al. 2020a). The amount of litter produced by grazing significantly affects the relative abundance of fungal saprophytes, while longterm overgrazing can cause changes in the development of the soil AMF system and adversely affect grassland ecosystem production (Guo et al. 2016; Hamonts et al. 2017). Thus, soil abiotic conditions can modify plant community composition-production relationships via changes in the biotic interplay among fungal groups as well as via changes in their interactions with plants. However, to our knowledge, empirical evidence on how fungal communities in surface and subsurface soils integrate the linkages of plant community composition and production under grassland disturbances is lacking.

The Inner Mongolian grassland is one of the best-known rangelands in the eastern part of the Eurasian steppe (Wang 2004). Here, Baoyin et al. (2014) concluded that the best practice for haymaking from grassland should be based on the rule of 'mowing once a year' and a light grazing early in the season may increase hay quality mowed in the autumn if the grassland grows well early in the season in highproduction years. Here, we examined the impacts of different grassland disturbances (grazing, mowing, and grazing+mowing) on the plant community and soil fungal guilds in different soil horizons of steppe grasslands in China. We further characterized the relationships between the characteristics (richness, abundance, and composition) of three fungal guilds (saprophytic fungi, mycorrhizal fungi, and potential plant pathogens) and plant community composition-production relationship. We tested the following two hypotheses: first, the fungal guilds primarily involved in plant community composition-production relationships differ between surface and subsurface soils; second, plant community compositionproduction relationships are mainly influenced by fungal functional guilds in the surface soil.

\section{Materials And Methods}

\section{Study design}

This study was conducted at the Typical Grassland Ecosystem Research Station (TGERS; 44॰9'18"N, 116.23'32"E, $1101 \mathrm{~m}$ asl), located in Xilinhot, Inner Mongolia, China (Chen et al. 2021). The research area has a temperate semi-arid continental climate, with the mean annual temperature of $3.5^{\circ} \mathrm{C}$, and the mean annual precipitation of $270.78 \mathrm{~mm}, 80 \%$ of which occurs during the growing season (May to September) when the temperatures are high (China Meteorological Data Sharing Service System). The soil at the station is Calciustoll according to FAO/Unesco System of Soil Classification. The research area was used as a free-range pasture with low stocking rates, but grazing ended in 2011. The vegetation in this region is characterized as typical xerophyte vegetation. The dominant plant species were Leymus chinensis, Stipa grandis, Stipa krylovii Roshev, and Cleistogenes squarrosa, of which Leymus chinensis (Trin.) Tzvel. and Stipa krylovii Roshev in concert taken up more than $90 \%$ of the whole above-ground biomass. 
The experiment was established in 2012 to study the effects of grassland for mowting and grazing on steppe ecosystems. In a randomized block design (Fig. S1), each of the four grassland management treatments had three replications, resulting in a total of 12 paddocks $\left(33.3 \times 33.3 \mathrm{~m}^{2}\right)$. The experiment included four treatments: no treatment (Control: enclosure and grazing prohibited since 2012), grazing (G: grazing twice in June \& August each year), grazing + mowing (GM, grazing once in June and mowing once in August each year), and mowing ( $M$, mowing once in August each year). Six Ugandan sheep were grazed in the grassland paddock on the $20^{\text {th }}$ of the designated month. The flock was removed once the average remaining height of $L$. chinensis was $6 \mathrm{~cm}$, which corresponded to moderate. Mowing treatments were implemented every year at the time of peak plant biomass (20th of the designated month) at the stubble height of approximately $6 \mathrm{~cm}$ (Fig. S1).

\section{Plant community investigation, soil sampling and analysis}

Soil samples and plant were collected in belated August 2019. Plant communities were surveyed within each plot using three $1 \times 1 \mathrm{~m}$ sample boxes to measure plant species abundance and above-ground biomass. In each sample box, plant species were identified and the abundance of each species was calculated by bundle or stem. Plant above-ground biomass (AGB) was found out through baking them at $65 \circ \mathrm{C}$ for $48 \mathrm{~h}$ to keep their weight unvarying and mowing all living plants to the land.

After the vegetation community investigation, an auger of $7 \mathrm{~cm}$ was used by us in diameter to gather surface $(0-10 \mathrm{~cm})$ and subsurface $(10-20 \mathrm{~cm})$ soils from each quadrat. The samples were placed in liquid nitrogen immediately and took back to the lab. A portion of the fresh soil samples were stored frozen at $-80^{\circ} \mathrm{C}$ and used to measure soil bacterial and fungal communities. A portion of the fresh soil samples were stored frozen at $-20^{\circ} \mathrm{C}$ and used to measure soil moisture (SM), bulk density (SBD), $\mathrm{pH}$, ammonium nitrogen ( $\mathrm{NH} 4+-\mathrm{N})$, nitrate nitrogen (NO3--N) and available phosphorus (SAP). A portion of the fresh soil samples were air dried and used to measure soil total carbon (STC), total nitrogen (STN) and separate (sandy, 50-2000 $\mu \mathrm{m}$; silt, 2-50 $\mu \mathrm{m}$; and clay, $<2 \mu \mathrm{m}$ ). $\mathrm{NO}_{3}{ }^{-} \mathrm{N}^{-}$and $\mathrm{NH}_{4}{ }^{+}-\mathrm{N}$ were determined using a Flow-Solution analyzer (AA3; SEAL, Germany). Soil total carbon (STC) and total nitrogen (STN) were determined with the element analyzer (Vario MACRO CUBE, Germany). The soil pH was measured using a pH meter (UV-1800; Shimadzu) for a 1: 5 soil: water suspension. SAP was determined using an ultraviolet-visible (UV-vis) light spectrophotometer (UV-1800; Shimadzu) via the molybdenum blue method. The soil separate was measured by Microtrac (USA). According to USDA, the soil separate was divided into three types: sandy $(0.05-2 \mathrm{~mm}, 50-2000 \mu \mathrm{m})$, silt $(0.002-0.05 \mathrm{~mm}, 2-50 \mu \mathrm{m})$, and clay (< $0.002 \mathrm{~mm}, 2 \mu \mathrm{m}$ ). Soil bulk density (SBD) was determined using the ring shear testing. Soil moisture content (SM) was measured by the oven-drying method.

Total genome DNA was extracted from five replicates of soil samples $(0.25 \mathrm{~g})$ using the PowerSoil DNA Isolation Kit (Mo Bio Laboratories Inc., Carlsbad, CA, USA) according to the manufacturer's instructions, and quantified using a NanoDrop UV-vis light spectrophotometer (ND-2000c; NanoDrop Technologies, Wilmington, DE, USA). DNA concentration was determined by fluorometric analysis with a microplate 
reader (BioTek, FLx800) prior to storage at $-80^{\circ} \mathrm{C}$. Amplicons targeting the fungal ITS genes of distinct regions (ITS1) were amplified using specific primers (ITS1F: 5'-GGAAGTAAAAGTCGTAACAAGG-3' and ITS1R: 5'-GCTGCGTTCTTCATCGATGC-3') (Orgiazzi et al., 2012). PCR amplification was carried out using PFU high fidelity DNA polymerase (TransGen Biotech, Beijing, China). Amplification product magnetic bead purification recovery was performed by adding $25 \mu \mathrm{L}$ of the PCR product to 0.8 times the volume of magnetic beads (Vazyme VAHTSTM DNA Clean Beads), shaking to fully suspend, and then adsorbing on a magnetic rack for $5 \mathrm{~min}$, carefully aspirating the supernatant with a pipette gun; subsequently, $20 \mu \mathrm{L}$ of 0.8 times the volume of magnetic bead washing solution were added, shaken to fully suspend, and then placed on a magnetic rack for adsorption for $5 \mathrm{~min}$, carefully aspirating the supernatant. Then, $200 \mu \mathrm{L}$ of $80 \%$ ethanol were added, the placement on the magnetic rack was reversed, solution was adsorbed to the other side of the PCR tube with magnetic beads, and the supernatant was aspirated. The PCR amplification recovery products were subjected to fluorescence quantification. Quantitative PCR (qPCR) was used fluorescence quantification with the fluorescence reagent Quant-iT PicoGreen dsDNA Assay Kit (Invitrogen, Carlsbad, CA, USA), and a microplate reader (BioTek, Winooski, VT, USA) was used for quantification. Finally, sequencing libraries were prepared using Illumina's TruSeq Nano DNA LT Library Prep Kit. The UNITE database (release 8.0, https://unite.ut.ee/) (Koljalg et al. 2013) was used for the determination of fungal ITS sequences. Information on the richness and composition of fungi was obtained by Majorbio BioPharm Biotechnology Co., Ltd., Shanghai, China. by performing ITS gene amplicon sequencing on the Illumina MiSeq platform. The acquired raw ITS sequence data were sorted into valid reads after demultiplexing and quality filtering using the classify-sklearn algorithm of the Quantitative Insights into Microbial Ecology (QIIME2; 2019.4) pipeline (https://github.com/QIIME2/q2feature-classifier) (Bolyen et al. 2018). Pre-trained Naive Bayes classifier in the QIIME2 software was used for species annotation with default parameters. High-quality sequences were assigned to operational taxonomic units (OTUs) at a $3 \%$ dissimilarity cutoff using qiime feature-table rarefy function in the QIIME2 software. Then, the non-chimeric sequences were re-clustered at $97 \%$ to generate OTU representative sequences and an OTU table.

The OTUs were further assigned to fungal functional guilds (i.e., saprotrophs, plant pathogens, orchid mycorrhizal fungi, dark septate endophyte fungi, endomycorrhizal fungi, ectomycorrhizal fungi, AMF, lichenized fungi, fungal parasites, endophytes, animal pathogens) according to Nguyen et al. (2016) (Table S1). To investigate plant community composition-production relationships, we focused on the roles of three functional guilds, namely saprotrophic fungi, potential plant pathogens, and mycorrhizal fungi.

\section{Data analyses}

One-way ANOVA was used to calculate the differences in plant aboveground production, richness of fungal functional guilds, and properties of surface and subsurface soils under different grassland disturbances using the 'ANOVA' function in the multcomp package in R (v. 3.3.2; R Core Team, 2017). Paired t-test (using the 't. test' function in R) was used to test the overall differences among the plant, 
microbial, and soil properties. Using the 'cap scale' function of the vegan package in R, principal coordinate analysis (PCOA) and analysis of similarity (ANOSIM) were carried out based on Bray-Curtis distance. The first coordinate of the PCoA (PCoA1) was used to represent the major variation in plant community composition (PCOM) and fungal functional composition in subsequent analyses.

Relationships between plant community composition (PCoA1 of plants) and aboveground production were examined using linear regression analysis. Random forest (RF) classification (Breiman 2001) was conducted to predict which of the three fungal functional groups in surface and subsurface soils were primarily associated with plant community composition and aboveground production in terms of abundance, richness, and community composition. The importance of each fungal characteristic in which the percentage increased in the mean square error (MSE) was determined using the 'randomForest' function of the randomForest package v. 4.6-14 in R. Significance level of the entire model and crossvalidated $R^{2}$ values were examined using 5,000 permutations of the response variables (plant community composition and aboveground biomass) via the 'a3' function of the A3 package.

Fungal characteristics were preselected by RF as common significant predictors of plant community composition and aboveground biomass, as well as soil physicochemical variables that showed significant correlations with plant or fungal characteristics. Linear regression was then used to assess the relationships between these fungal characteristics. The 'carport' and 'RDA' functions of the vegan package in $\mathrm{R}$ were used to conduct a variation partitioning analysis (VPA) of plant components using the abovementioned fungal characteristics and edaphic variables. This process provided a complementary understanding of the shared and independent contributions of these specific categories at both surface and subsurface soils (Tedersoo et al. 2016; Chen et al. 2019).

Subsequently, structural equation modeling (SEM) was performed using the AMOS 22.0 software (SPSS, IBM, NY, USA) to obtain a systematic understanding of direct and indirect relationships between fungal characteristics, soil abiotic variables, and plant components. Additionally, SEM was used to evaluate whether the relationships between soil fungal characteristics, plant community composition, and aboveground production were maintained after simultaneously accounting for multiple factors. A priori model was first established based on the known effects and relationships among these variables (Table S2; Fig. S2). The data set was fitted to the model using the maximum likelihood estimation method. The initial model was adjusted and re-evaluated by stepwise removal of non-significant relationships until all pathways represented significant contributors to the final model. It should be noted that there is no single universally accepted goodness of fit test for SEM. Thus, evaluation of goodness of fit of the final model was based on the chi-squared (v2) test, and the fit was deemed acceptable when $0 \leq \mathrm{v} 2 / \mathrm{df} \leq 2$ and 0.05 $<\mathrm{P} \leq 1.00$ and when the root-mean-square error of approximation (RMSEA) was $0 \leq \mathrm{RMSEA} \leq 0.05$ and $0.10<\mathrm{P} \leq 1.00$.

To mitigate deviations from normality, before the analysis, the abundances of rhizosphere fungal guilds were square transformed, and aboveground biomass and soil properties (soil moisture, soil bulk density, 
$\mathrm{pH}, \mathrm{NO}_{3}{ }^{-} \mathrm{N}, \mathrm{NH}_{4}{ }^{+}-\mathrm{N}, \mathrm{SAP}, \mathrm{STN}, \mathrm{STC}$, soil $\mathrm{C} / \mathrm{N}$, and soil separate) were $\mathrm{Ln}$ transformed. All analyses were conducted independently for the surface and subsurface soils.

\section{Results}

\section{Plant and soil characteristics in grasslands under different disturbances}

Plant aboveground production was significantly lower in the disturbed grasslands than in the control grasslands (Fig. 1a). A negative linear relationship was observed between plant community composition and plant aboveground production (Fig. 1b). Disturbances altered the composition of plant functional groups, with a substantial decrease in the relative abundance of annual/biennial forbs and a substantial increase in perennial forbs (Fig. 1c). Plant community composition differed between the disturbance treatments and the control according to principal coordinate analyses (PCOA) based on the Bray-Curtis distance (Fig. 1d; PERMANOVA: $F=6.1706, R^{2}=0.481, P=0.002$ ).

In the surface soil $(0-10 \mathrm{~cm})$, grazing, grazing+mowing, and mowing resulted in significantly higher soil bulk density and soil $\mathrm{C}: \mathrm{N}$ than those in the control, but with no differences among these variables under grazing, grazing+mowing, and mowing (Table S3). Among the three disturbances, grazing resulted in the lowest STN and STC, whereas mowing resulted in the highest STN and STC $(P<0.05$; Table S3). In the subsurface soil $(10-20 \mathrm{~cm})$, no significant differences in any soil physical and chemical factor were found among the disturbances and the control (Table S3). Significantly lower soil moisture and silt content were observed in the surface soil than in the subsurface soil, whereas the content of sand was higher in the surface soil than in the subsurface soil $(P<0.05)($ Table S3).

\section{Fungal community composition}

In total, the surface and subsurface soil yielded 1,573,351 and 1,738,851 high-quality sequences, which were clustered into 3,683 and 2,797 fungal OTUs, respectively, at $97 \%$ sequence identity (Fig. S3a). In terms of functional composition, $41.9 \%$ of all fungal sequences obtained for the surface soil and $45.8 \%$ of all fungal sequences obtained for the subsurface soil were assigned to 11 fungal functional guilds (Fig. 2, Fig. S3b). Saprotrophic fungi, potential plant pathogens, and mycorrhizal fungi were the primary functional guilds. Saprotrophic fungi accounted for $50.4 \%, 73.1 \%, 55.7 \%$, and $68.6 \%$ of fungi in the control, grazed, grazed+mowed, and mowed surface soil, respectively, and $48.6 \%, 69.0 \%, 55.5 \%$, and $55.1 \%$ in the control, grazed, grazed+mowed, and mowed subsurface soil, respectively (Fig. 2a, b). Potential plant pathogens accounted for $28.5 \%, 9.8 \%, 12.9 \%$, and $11.2 \%$, of control, grazed, grazed+mowed, and mowed surface soil, respectively, and $19.4 \%, 10.8 \%, 16.9 \%$, and $22.1 \%$ of control, grazed, grazed+mowed, and mowed subsurface soil, respectively (Fig. 2a, b). Mycorrhizal fungi accounted for $2.0 \%, 0.7 \%, 1.0 \%$, and $0.8 \%$ of control, grazed, grazed+mowed, and mowed surface soil, 
respectively, and $3.9 \%, 1.1 \%, 1.8 \%$, and $1.8 \%$ of control, grazed, grazed+mowed, and mowed subsurface soil, respectively (Fig. 2a, b).

In the surface soil, grazing significantly reduced the richness of saprophytic fungi and potential plant pathogens compared to those in the control, and grazing+mowing significantly reduced the richness of saprophytic fungi compared to that in the control. However, there were no differences in the richness of mycorrhizal fungi between control and disturbed grasslands (Fig. 2c). However, in the subsurface soil, the richness of all fungal functional guilds was not significantly changed by grazing, grazing+mowing, and mowing compared to that in the control (Fig. 2d).

In the surface soil, the community composition of potential plant pathogens differed among soils under grazing, grazing+mowing, and mowing treatments compared with that in the control (PERMANOVA: $F=$ $2.149, R^{2}=0.446, P=0.004$ ) (Fig. 2f). However, the community composition of saprotrophic fungi and mycorrhizal fungi did not differ among the soils under grazing, grazing+mowing, and mowing treatments (PERMANOVA: $F=1.178, R^{2}=0.306, P=0.095$ for saprotrophic fungi; $F=0.607, R^{2}=0.186, P=0.936$ for mycorrhizal fungi) (Fig. 2e, g). In the subsurface soil, significant differences were found in the saprotrophic fungal community composition between the soils under the control and grassland disturbance treatments (PERMANOVA: $\left.F=1.426, R^{2}=0.348, P=0.002\right)$ (Fig. 2h). However, in the subsurface soil, no differences in community composition of potential plant pathogens (PERMANOVA: $F$ $\left.=1.505, R^{2}=0.361, P=0.034\right)$ and mycorrhizal fungi (PERMANOVA: $F=0.930, R^{2}=0.259, P=0.644$ ) (Fig. 2i, j) were found between the control and any of the disturbance treatments.

\section{Relationships between plant production-community composition and associated fungal guilds}

Correlations were observed between pairs of fungal guilds in both surface and subsurface soils, and they varied substantially between the horizons (Fig. S4). In the surface soil, according to the random forest analysis and prediction results, plant aboveground production was co-predicted by abundance of potential plant pathogens and abundance of saprotrophic fungi, while community composition was copredicted by abundance of potential plant pathogens and PCoA axis 1 for saprotrophic fungi (SaPCoA1) (Fig. S5a, b). In the subsurface soil, the random forest analysis indicated that the richness of saprotrophic fungi and PCoA axis 1 for potential plant pathogens (PpPCoA1) were the main fungal variables for predicting plant aboveground production. Richness of mycorrhizal fungi and PpPCoA1 were the main fungal variables for predicting plant community composition (Fig. S5c, d). Concerning the guild characteristics identified as the key predictors of both plant aboveground production and community composition, richness of mycorrhizal fungi showed no correlation with PpPCoA1 in the subsurface soil (Fig. S4).

In the surface soil, the abundance of potential plant pathogens had significantly positive linear relationship with plant aboveground production and a significantly negative linear relationship with plant 
community composition (Fig. 3a, b). Partial regression analysis was carried out without considering the influence of soil abiotic variables, and the results indicated that the abundance of potential plant pathogens had a significantly positive linear relationship with plant aboveground production.

Furthermore, abundance of saprotrophic fungi had a significantly negative linear relationship with plant community composition (Fig. 3a, b; Table S4). The VPA showed that the combined effects of abundance of potential plant pathogens, abundance of saprotrophic fungi, and edaphic variables explained more of the variation in plant aboveground production (34.92\%) than either of these factors did alone; the combined effects of abundance of potential plant pathogens and abundance of saprotrophic fungi explained $22.32 \%$ of the variation in plant aboveground production (Fig. 3c). Edaphic variables alone explained more of the variation in plant community composition (73.31\%), followed by the combined effects of the abundance of potential plant pathogens, abundance of saprotrophic fungi, and edaphic variables, which explained $36.34 \%$ of the variation in plant aboveground production (Fig. 3d). Together, plant aboveground production and community composition accounted for most of the variation in the abundance of potential plant pathogens and abundance of saprotrophic fungi in the surface soil (Fig. 3e, f).

In the subsurface soil, although the richness of mycorrhizal fungi showed no correlation with either plant aboveground production or community composition, PpPCoA1 had a significantly negative linear relationship with plant aboveground production and no correlation with plant community composition (Fig. S6d, f). After controlling for the effects of shared edaphic variables, the relationships of PpPCoA1 and richness of mycorrhizal fungi with both plant aboveground production and plant community composition were still significant (Fig. 4a, b; Table S5). The VPA showed that PpPCoA1 explained most of the variation in plant aboveground production (21.69\%); however, compared to PpPCoA1 and richness of mycorrhizal fungi, edaphic variables explained more of the variation in plant community composition (Fig. 4c, d). Moreover, plant aboveground production and community composition together accounted for most of the variation in PpPCoA1 in the subsurface soil (Fig. 3e).

SEM explained $93.8 \%$ and $60.6 \%$ of the variation in plant aboveground production and community composition in the surface soil, respectively (Fig. 5a; Table S6). Furthermore, it explained $97.8 \%$ and $78.8 \%$ of the variation in the abundance of potential plant pathogens and abundance of saprotrophic fungi in the surface soil, respectively (Fig. 5a). In the surface soil, plant aboveground production was directly and significantly negatively affected by $\mathrm{NO}_{3}{ }^{-}-\mathrm{N}$ and positively affected by $\mathrm{NH}_{4}{ }^{+}-\mathrm{N}$, whereas plant community composition was directly and significantly negatively affected by soil available phosphorous and positively affected by $\mathrm{NO}_{3}{ }^{-} \mathrm{N}$ (Fig. 5a). Direct and positive impacts of soil moisture and $\mathrm{NO}_{3}{ }^{-} \mathrm{N}$, and negative impacts of soil bulk density, available phosphorous, and $\mathrm{NH}_{4}{ }^{+}-\mathrm{N}$ on the abundance of potential plant pathogens were observed. Soil $\mathrm{NH}_{4}{ }^{+}-\mathrm{N}$ and $\mathrm{NO}_{3}{ }^{-} \mathrm{N}$ directly and positively affected the abundance of saprotrophic fungi. In contrast, soil moisture, bulk density, and available phosphorous directly negatively affected the abundance of saprotrophic fungi (Fig. 5a). Abundance of saprotrophic fungi and plant community composition had indirect effects on plant aboveground production by influencing the abundance of potential plant pathogens. Abundance of potential plant pathogens had significantly 
positive effects on plant aboveground production (Fig. 5a). Furthermore, plant community composition and abundance of saprotrophic fungi had significantly negative effects on the abundance of potential plant pathogens (Fig. 5a). SEM explained $94.1 \%$ and $40.7 \%$ of the variation in plant aboveground production and community composition in the subsurface soil, respectively (Fig. 5b; Table S7). Furthermore, it explained $6.6 \%$ and $66.2 \%$ of the variation in PpPCoA1 and richness of mycorrhizal fungi in the subsurface soil, respectively (Fig. 5b). In the subsurface soil, plant aboveground production was directly and significantly positively affected by $\mathrm{NO}_{3}{ }^{-} \mathrm{N}$ and $\mathrm{NH}_{4}{ }^{+}-\mathrm{N}$ (Fig. 5b). Richness of mycorrhizal fungi was directly and significantly positively affected by soil moisture, available phosphorous, and $\mathrm{NO}_{3}{ }^{-}-$ $\mathrm{N}$ (Fig. 5b). PpPCoA1 directly and significantly positively affected plant community composition as well as plant aboveground production. Plant aboveground production was also significantly negatively affected by PpPCoA1 (Fig. 5b). Furthermore, richness of mycorrhizal fungi had negative effects on PpPCoA1 (Fig. 5b).

\section{Discussion}

\section{Associations of fungal guilds from the two soil horizons with plant production and community composition under disturbances}

Grazing and mowing disturbances lead to heterogeneity in the availability of exogenous nutrients in the soil (Fóti et al. 2017), which impacts the soil microenvironment (Li et al. 2017), nutrient availability, fungal community structure, soil fungal activity (Józefowska et al. 2018), and interactions among soil fungal guilds (Grau et al. 2017). Under grassland disturbance, the return of plant exudates, litter (Kardol \& Wardle 2010), and feces and urine (Bagchi \& Ritchie 2010) provides inputs of carbon and nitrogen to the surface soil, resulting in significant changes in the abundance of saprophytic fungi and potential plant pathogens (Millard \& Singh 2009; Wen et al. 2020). In the present study, grazing and grazing+mowing significantly reduced the richness of saprophytic fungi and potential plant pathogens in the surface soil. In contrast, no significant changes were observed in the richness of mycorrhizal fungi under the grazing, mowing, and grazing+mowing treatments. However, these changes were less pronounced in the subsurface soil than in the surface soil. Grassland disturbances significantly altered the community composition of potential plant pathogens in both the surface and subsurface soil, as well as the community composition of saprotrophic fungi in the subsurface soil. Grassland disturbance influences plant indexes (including plant species diversity, abundance, aboveground biomass, and functional composition), which can affect the spread and infection of potential plant pathogens (Rottstock et al. 2014). Therefore, the addition of exogenous nutrients to the surface soil, especially the return of feces and urine, was the main factor causing the changes in abundance and community composition of saprotrophic fungi and potential plant pathogens. Mycorrhizal fungi obtain carbohydrates from host plants (Parniske 2008; Ji \& Bever 2016); therefore, improving plant aboveground production can increase 
the richness of mycorrhizal fungi (Wagg et al. 2011). In the present study, we observed no significant changes in the richness and community composition of mycorrhizal fungi and dominant plant species.

The species-energy theory explains that species number increases with the increase in total available energy (Whittaker 2006). In natural ecosystems, structure and function of the surface soil microbiome may be strongly altered as a consequence of shifts in plant communities related to disturbances (Bahram et al. 2020). In the present study, we found a negative relationship between plant production and community composition, which was consistent with the findings of Fraser et al. (2015). Furthermore, we observed positive associations between the abundance of potential plant pathogens (APp) and plant production (APP), as well as negative associations between the abundance of saprophytic fungi in the surface soil and plant production. There is an antagonistic relationships between the abundance of saprophytic fungi and potential plant pathogens in surface soil, which may be related to nutrient limitation or competitive exclusion (Grau et al. 2017; Liu et al. 2020). However, in the present study, no simultaneously significant associations were found between these two fungal guilds and plant composition. This was consistent with the findings of Mommer et al. (2018). The complex interactions between functional fungal communities and plant community vary greatly between surface and subsurface soils (Grau et al. 2017; Kyaschenko et al. 2017a; Kyaschenko et al. 2017b). In the present study, in the subsurface soil, there was a negative association between the PCoA axis 1 for potential plant pathogens and plant production and a positive association between the PCoA axis 1 for potential plant pathogens and plant composition. The relationship between plant pathogenic fungi and plant production was the opposite in the surface and subsurface soil. By specifically suppressing dominant plants, soil pathogens may contribute to the maintenance of stable plant community composition (Bever et al. 1997). Schnitzer et al. (2011) found that soil pathogens reduced plant production when plant community composition was low and increased it when plant community composition was high. Therefore, fungal root pathogens were important drivers of biodiversity-ecosystem function relationships (Mommer et al. 2018).

\section{Interaction between fungal guilds driving the plant production-community composition relationship vary between soil horizons}

In the present study, significant differences in the interactions between functional fungal communities were observed between different soil horizons. This was supported by previous observations of natural habitats with contrasting abiotic conditions (Grau et al. 2017), indicating that the interactions among fungal functional groups are environmentally dependent. Chen et al. (2019) found that the abundances of saprotrophic and mycorrhizal fungi were positively correlated at sites with high nutrient contents, and that the abundances of mycorrhizal fungi and potential plant pathogens were negatively correlated at sites with low nutrient contents. In the present study, in the surface soil, plant production and community composition could jointly explain the higher rates of variation in pathogenic and saprophytic fungi, 
suggesting that plants also simultaneously influence fungal communities. The abundance of potential plant pathogens and saprophytic fungi together explained greater rates of variation in plant production and community composition, suggesting that these factors have a strong correlation with plant production and community composition. Yang et al. (2019) reported that high organic $\mathrm{C}$ and $\mathrm{N}$ contents in the soil were beneficial to the propagation of soil fungi, and they observed a high positive correlation between soil fungal diversity and organic $\mathrm{C}$ and $\mathrm{N}$ levels. Therefore, in the present study, the increased exogenous $\mathrm{SOC}$ and nutrients $\left(\mathrm{NO}_{3}{ }^{-} \mathrm{NH}_{4}{ }^{+}\right.$, and available $\left.\mathrm{P}\right)$ in grazing and grazing+mowing treatments may have led to an increase fungal diversity, which is consistent with our SEM results. Moreover, in previous studies, soil saprophytic fungi were positively correlated with $\mathrm{SOC}$ and $\mathrm{NH}_{4}{ }^{+}-\mathrm{N}(\mathrm{Li}$ et al. 2021), whereas potential plant pathogens were negatively correlated with plant community composition (Putten 2003; Heijden et al. 2008), saprophytic fungi (Grau et al. 2017; Liu et al. 2020), soil nutrients (Meng et al. 2019), and soil moisture (Latha et al. 2006).

In the subsurface soil, the PCoA axis 1 for potential plant pathogens and the richness of mycorrhizal fungi had a lower interpretation rate for plant production and community composition than that in the surface soil. This indicated that the subsurface fungal functional groups had little effect on plant production-community composition, which mainly occurs in surface soil. Potential plant pathogens have been recognized as drivers of plant production-community composition relationships through their negative density-dependent interactions with plants, causing a decrease in plant production (Maron et al. 2011; Schnitzer et al. 2011).

\section{Conclusion}

Empirical evidence has improved our understanding of the importance of soil fungal communities in the plant community composition-production relationship. In the present study, the grassland disturbance experiment conducted over the past decade has allowed us to observe stable relationships between plants, soils, and microorganisms, and our findings can be used as a basis for future studies on the relationships between plants, soil, and microbes. Our study showed that under grassland disturbance conditions, plant community composition and production were correlated with a soil horizon-related interplay between fungal guilds that have distinct biotic interactions with plants (specifically saprotrophs, mycorrhizal fungi, and potential plant pathogens). These co-existing fungal groups interact to drive plant community composition-production relationships, with fungal pathogens playing an important driver role. Furthermore, different fungal mechanisms related to the linkages of plant composition and production between soil horizons illustrate how the overall negative linkage of plant composition and production can be maintained under grassland disturbance conditions.

\section{Declarations}

To be used for all articles, including articles with biological applications

\section{Funding}


This work was financially supported by the National Natural Science Foundation of China (31860681) and the China Agriculture Research System (CARS-34).

\section{Conflicts of interest/Competing interests}

We declare that we have no financial and personal relationships with other people or organizations that can inappropriately influence our work, there is no professional or other personal interest of any nature or kind in any product, service and/or company that could be construed as influencing the position presented in, or the review of, the manuscript entitled, "Plant production-community composition relationship associated with fungal guilds depends on grassland disturbance in surface and subsurface soils".

\section{Availability of data and material}

All data generated or analyzed during this study are included in this published article [and its supplementary information files].

\section{Code availability}

All models and code generated or used during the study appear in the submitted article.

\section{Author contributions}

Huimin Bai and Zhiying Liu conceived the study. Material preparation and data analysis were performed by Huimin Bai. Data collection were performed by Huimin Bai, Tianyu Zhang, Tianqi Wang, Huizhen Li, and Hongbin Xu. The first draft of the manuscript was written by Huimin Bai and all authors commented on previous versions of the manuscript. All authors read and approved the final manuscript.

\section{Ethics approval}

Not applicable

\section{Consent to participate}

Not applicable

\section{Consent for publication}

Not applicable

\section{Acknowledgments}

We acknowledge the Typical Grassland Ecosystem Research Station (TGERS) for providing a research platform. This work was financially supported by the National Natural Science Foundation of China (31860681) and the China Agriculture Research System (CARS-34). 


\section{References}

1. Bagchi, S. \& Ritchie, M.E. (2010). Introduced grazers can restrict potential soil carbon sequestration through impacts on plant community composition. Ecol Lett, 13, 959-968. https://doi.org/10.1111/j.1461-0248.2010.01486.x

2. Bahram, M., Netherway, T., Hildebrand, F., Pritsch, K., Drenkhan, R., Loit, K. et al. (2020). Plant nutrientacquisition strategies drive topsoil microbiome structure and function. New Phytol, 227, 1189-1199. https://doi.org/10.1111/nph.16598

3. Baoyin, T., Li, F.Y., Bao, Q., Minggagud, H. \& Zhong, Y. (2014). Effects of mowing regimes and climate variability on hay production of Leymus chinensis (Trin.) Tzvelev grassland in northern China. The Rangeland Journal, 36. https://doi.org/10.1071/rj13088

4. Bardgett, R.D., Wardle, D.A. \& Yeates, G.W. (1998). Linking above-ground and below-ground interactions: How plant responses to foliar herbivory influence soil organisms. Soil Biol Biochem, 30, 1867-1878. https://doi.org/10.1016/s0038-0717(98)00069-8

5. Bever, J.D., Westover, K.M. \& Antonovics, J. (1997). Incorporating the soil community into plant population dynamics: the utility of the feedback approach. Journal of Ecology, 85, 561-573 https://doi.org/10.2307/2960528

6. Bolyen, E., Rideout, J.R., Dillon, M.R., Bokulich, N.A., Abnet, C., Al-Ghalith, G.A. et al. (2018). QIIME 2: Reproducible, interactive, scalable, and extensible microbiome data science. PeerJ Preprints. https://doi.org/10.7287/peerj.preprints.27295v1

7. Breiman, L. (2001). Random Forests. Machine Learning, 45, 5-32.

8. Chen, L., Xu, H., Wu, S. \& Baoyin, T. (2021). Plant and soil properties mediate the response of soil microbial communities to moderate grazing in a semiarid grassland of northern China. Journal of Environmental Management, 284. https://doi.org/10.1016/j.jenvman.2021.112005

9. Chen, Q.L., Ding, J., Li, C.Y., Yan, Z.Z., He, J.Z. \& Hu, H.W. (2020). Microbial functional attributes, rather than taxonomic attributes, drive top soil respiration, nitrification and denitrification processes. Sci Total Environ, 734, 139479. https://doi.org/10.1016/j.scitotenv.2020.139479

10. Chen, W., Wang, J., Meng, Z., Xu, R., Chen, J., Zhang, Y. et al. (2019). Fertility-related interplay between fungal guilds underlies plant richness-productivity relationships in natural grasslands. New Phytol. https://doi.org/10.1111/nph.16390

11. Chen, W., Xu, R., Chen, J., Yuan, X., Zhou, L., Tan, T. et al. (2018). Consistent responses of surfaceand subsurface soil fungal diversity to $\mathrm{N}$ enrichment are mediated differently by acidification and plant community in a semi-arid grassland. Soil Biology and Biochemistry, 127, 110-119. https://doi.org/10.1016/j.soilbio.2018.09.020

12. Chisté, Melanie N., Mody, K., Kunz, G., Gunczy, J. \& Blüthgen, N. (2018). Intensive land use drives small-scale homogenization of plant- and leafhopper communities and promotes generalists. Oecologia, 186, 529-540. https://doi.org/10.1007/s00442-017-4031-0 
13. DÍAz, S., Lavorel, S., Mclntyre, S.U.E., Falczuk, V., Casanoves, F., Milchunas, D.G. et al. (2007). Plant trait responses to grazing ? a global synthesis. Global Change Biology, 13, 313-341. https://doi.org/10.1111/j.1365-2486.2006.01288.x

14. Eldridge, D.J. \& Delgado-Baquerizo, M. (2017). Continental-scale Impacts of Livestock Grazing on Ecosystem Supporting and Regulating Services. Land Degradation \& Development, 28, 1473-1481. https://doi.org/10.1002/ldr.2668

15. Fóti, S., Balogh, J., Papp, M., Koncz, P., Hidy, D., Csintalan, Z. et al. (2017). Temporal Variability of CO2 and N2O Flux Spatial Patterns at a Mowed and a Grazed Grassland. Ecosystems, 21, 112-124. https://doi.org/10.1007/s10021-017-0138-8

16. Frąc, M., Hannula, S.E., Betka, M. \& Jędryczka, M. (2018). Fungal biodiversity and their role in soil health. Frontiers in Microbiology, 9. https://doi.org/10.3389/fmicb.2018.00707

17. Fraser, L.H., Pither, J., Jentsch, A., Sternberg, M., Zobel, M., Askarizadeh, D. et al. (2015). Worldwide evidence of a unimodal relationship between productivity and plant species richness.

18. Gong, J.-R., Wang, Y., Liu, M., Huang, Y., Yan, X., Zhang, Z. et al. (2014). Effects of land use on soil respiration in the temperate steppe of Inner Mongolia, China. Soil and Tillage Research, 144, 20-31. https://doi.org/10.1016/j.still.2014.06.002

19. Grau, O., Geml, J., Perez-Haase, A., Ninot, J.M., Semenova-Nelsen, T.A. \& Penuelas, J. (2017). Abrupt changes in the composition and function of fungal communities along an environmental gradient in the high Arctic. Mol Ecol, 26, 4798-4810. https://doi.org/10.1111/mec.14227

20. Guo, Q., Yan, L., Korpelainen, H., Niinemets, Ü. \& Li, C. (2019). Plant-plant interactions and N fertilization shape soil bacterial and fungal communities. Soil Biology and Biochemistry, 128, 127138. https://doi.org/10.1016/j.soilbio.2018.10.018

21. Guo, Y., Du, Q., Li, G., Ni, Y., Zhang, Z., Ren, W. et al. (2016). Soil phosphorus fractions and arbuscular mycorrhizal fungi diversity following long-term grazing exclusion on semi-arid steppes in Inner Mongolia. Geoderma, 269, 79-90. https://doi.org/10.1016/j.geoderma.2016.01.039

22. Hamilton, E.W. \& Frank, D.A. (2001). Can plants stimulate soil microbes and their own nutrient supply? Evidence from a grazing tolerant grass. Ecology, 82, 2397-2402.

https://doi.org/10.1890/0012-9658(2001)082[2397:Cpssma]2.0.Co;2

23. Hamonts, K., Bissett, A., Macdonald, B.C.T., Barton, P.S., Manning, A.D. \& Young, A. (2017). Effects of ecological restoration on soil microbial diversity in a temperate grassy woodland. Applied Soil Ecology, 117-118, 117-128. https://doi.org/10.1016/j.apsoil.2017.04.005

24. Heijden, M.G.A.v.d., Bardgett, R.D. \& Straalen, N.M.v. (2008). The unseen majority: soil microbes as drivers of plant diversity and productivity in terrestrial ecosystems. Ecol Lett, 11, 296-310. https://doi.org/10.1111/j.1461-0248.2007.01139.x

25. Ingram, L.J., Stahl, P.D., Schuman, G.E., Buyer, J.S., Vance, G.F., Ganjegunte, G.K. et al. (2008). Grazing Impacts on Soil Carbon and Microbial Communities in a Mixed-Grass Ecosystem. Soil Science Society of America Journal, 72. https://doi.org/10.2136/sssaj2007.0038 
26. Ji, B. \& Bever, J.D. (2016). Plant preferential allocation and fungal reward decline with soil phosphorus: implications for mycorrhizal mutualism. Ecosphere, 7, 1-11.

https://doi.org/10.1002/ecs2.1256

27. Józefowska, A., Zaleski, T., Zarzycki, J. \& Frączek, K. (2018). Do mowing regimes affect plant and soil biological activity in the mountain meadows of Southern Poland? Journal of Mountain Science, 15, 2409-2421. https://doi.org/10.1007/s11629-018-4953-y

28. Kardol, P. \& Wardle, D.A. (2010). How understanding aboveground-belowground linkages can assist restoration ecology. Trends Ecol Evol, 25, 670-679. https://doi.org/10.1016/j.tree.2010.09.001

29. Koljalg, U., Nilsson, R.H., Abarenkov, K., Tedersoo, L., Taylor, A.F., Bahram, M. et al. (2013). Towards a unified paradigm for sequence-based identification of fungi. Mol Ecol, 22, 5271-5277. https://doi.org/10.1111/mec.12481

30. Kyaschenko, J., Clemmensen, K.E., Hagenbo, A., Karltun, E. \& Lindahl, B.D. (2017a). Shift in fungal communities and associated enzyme activities along an age gradient of managed Pinus sylvestris stands. ISME J, 11, 863-874. https://doi.org/10.1038/ismej.2016.184

31. Kyaschenko, J., Clemmensen, K.E., Karltun, E. \& Lindahl, B.D. (2017b). Below-ground organic matter accumulation along a boreal forest fertility gradient relates to guild interaction within fungal communities. Ecol Lett, 20, 1546-1555. https://doi.org/10.1111/ele.12862

32. Latha, V., Panneerselvam, A. \& Saravanamuthu, R. (2006). Effect of Physicochemical Factors of the Soil on the Competitive Saprophytic Colonization of Sclerotium rolfsii. Agricultural Science Digest, $26,215-217$.

33. Li, J., Xu, X., Zhang, Q., Xu, J., Li, Y., Liu, J. et al. (2017). Impact of mowing management on nitrogen mineralization rate and fungal and bacterial communities in a semiarid grassland ecosystem. Journal of Soils and Sediments, 17, 1715-1726. https://doi.org/10.1007/s11368-016-1620-1

34. Li, W.-Q., Huang, Y.-X., Chen, F.-S., Liu, Y.-Q., Lin, X.-F., Zong, Y.-Y. et al. (2021). Mixing with broadleaved trees shapes the rhizosphere soil fungal communities of coniferous tree species in subtropical forests. Forest Ecology and Management, 480.

https://doi.org/10.1016/j.foreco.2020.118664

35. Liu, C., Gong, X., Dang, K., Li, J., Yang, P., Gao, X. et al. (2020). Linkages between nutrient ratio and the microbial community in rhizosphere soil following fertilizer management. Environ Res, 184, 109261. https://doi.org/10.1016/j.envres.2020.109261

36. Liu, J., Sui, Y., Yu, Z., Shi, Y., Chu, H., Jin, J. et al. (2015). Soil carbon content drives the biogeographical distribution of fungal communities in the black soil zone of northeast China. Soil Biology and Biochemistry, 83, 29-39. https://doi.org/10.1016/j.soilbio.2015.01.009

37. Liu, S., Zamanian, K., Schleuss, P.-M., Zarebanadkouki, M. \& Kuzyakov, Y. (2018). Degradation of Tibetan grasslands: Consequences for carbon and nutrient cycles. Agr Ecosyst Environ, 252, 93-104. https://doi.org/10.1016/j.agee.2017.10.011

38. Lozano, Y.M., Armas, C., Hortal, S., Casanoves, F. \& Pugnaire, F.I. (2017). Disentangling above- and below-ground facilitation drivers in arid environments: the role of soil microorganisms, soil properties 
and microhabitat. New Phytol, 216, 1236-1246. https://doi.org/10.1111/nph.14499

39. Maron, J.L., Marler, M., Klironomos, J.N. \& Cleveland, C.C. (2011). Soil fungal pathogens and the relationship between plant diversity and productivity. Ecol Lett, 14, 36-41.

https://doi.org/10.1111/j.1461-0248.2010.01547.x

40. Meng, T., Wang, Q., Abbasi, P. \& Ma, Y. (2019). Deciphering differences in the chemical and microbial characteristics of healthy and Fusarium wilt-infected watermelon rhizosphere soils. Appl Microbiol Biotechnol, 103, 1497-1509. https://doi.org/10.1007/s00253-018-9564-6

41. Millard, P. \& Singh, B.K. (2009). Does grassland vegetation drive soil microbial diversity? Nutrient Cycling in Agroecosystems, 88, 147-158. https://doi.org/10.1007/s10705-009-9314-3

42. Mommer, L., Cotton, T.E.A., Raaijmakers, J.M., Termorshuizen, A.J., van Ruijven, J., Hendriks, M. et al. (2018). Lost in diversity: the interactions between soil-borne fungi, biodiversity and plant productivity. New Phytol, 218, 542-553. https://doi.org/10.1111/nph.15036

43. Nguyen, N.H., Song, Z., Bates, S.T., Branco, S., Tedersoo, L., Menke, J. et al. (2016). FUNGuild: An open annotation tool for parsing fungal community datasets by ecological guild. Fungal Ecology, 20, 241-248. https://doi.org/10.1016/j.funeco.2015.06.006

44. Parniske, M. (2008). Arbuscular mycorrhiza: the mother of plant root endosymbioses. Nat Rev Microbiol, 6, 763-775. https://doi.org/10.1038/nrmicro1987

45. Putten, W.H., Bradford, M.A., Pernilla Brinkman, E., Voorde, T.F.J., Veen, G.F. \& Bailey, J.K. (2016). Where, when and how plant-soil feedback matters in a changing world. Functional Ecology, 30, 1109-1121. https://doi.org/10.1111/1365-2435.12657

46. Putten, W.H.V.d. (2003). Plant defense belowground and spatiotemporal processes in natural vegetation. Ecology, 84, 2269-2280.

47. Rottstock, T., Joshi, J., Kummer, V. \& Fischer, M. (2014). Higher plant diversity promotes higher diversity of fungal pathogens, while it decreases pathogen infection per plant. Ecology, 95, 19071917. https://doi.org/10.1890/13-2317.1

48. Schnitzer, S.A., Klironomos, J.N., Hillerislambers, J., Kinkel, L.L., Reich, P.B., Xiao, K. et al. (2011). Soil microbes drive the classic plant diversity-productivity pattern. Ecology, 92, 296-303. https://doi.org/10.1890/10-0773.1

49. Schönbach, P., Wan, H., Gierus, M., Bai, Y., Müller, K., Lin, L. et al. (2011). Grassland responses to grazing: effects of grazing intensity and management system in an Inner Mongolian steppe ecosystem. Plant and Soil, 340, 103-115. https://doi.org/10.1007/s11104-010-0366-6

50. Tardy, V., Spor, A., Mathieu, O., Lévèque, J., Terrat, S., Plassart, P. et al. (2015). Shifts in microbial diversity through land use intensity as drivers of carbon mineralization in soil. Soil Biology and Biochemistry, 90, 204-213. https://doi.org/10.1016/j.soilbio.2015.08.010

51. Tedersoo, L., Bahram, M., Cajthaml, T., Polme, S., Hiiesalu, I., Anslan, S. et al. (2016). Tree diversity and species identity effects on soil fungi, protists and animals are context dependent. ISME J, 10, 346-362. https://doi.org/10.1038/ismej.2015.116 
52. Vannucchi, F., Malorgio, F., Pezzarossa, B., Pini, R. \& Bretzel, F. (2015). Effects of compost and mowing on the productivity and density of a purpose-sown mixture of native herbaceous species to revegetate degraded soil in anthropized areas. Ecological Engineering, 74, 60-67.

https://doi.org/10.1016/j.ecoleng.2014.09.121

53. Wagg, C., Jansa, J., Stadler, M., Schmid, B. \& Heijden, M.G.A.V.D. (2011). Mycorrhizal fungal identity and diversity relaxes plant-plant competition. Ecology, 92, 1303-1313. https://doi.org/10.1890/101915.1

54. Wang, J., Liu, G., Zhang, C. \& Wang, G. (2020a). Effect of long-term destocking on soil fungal functional groups and interactions with plants. Plant and Soil, 448, 495-508. https://doi.org/10.1007/s11104-020-04452-0

55. Wang, R.Z. (2004). Photosynthetic Pathways and Life Form Types for Native Plant Species from Hulunbeier Rangelands, Inner Mongolia, North China. Photosynthetica, 42, 219-227. https://doi.org/10.1023/B:PHOT.0000040593.18169.18

56. Wang, X., Li, F.Y., Wang, Y., Liu, X., Cheng, J., Zhang, J. et al. (2020b). High ecosystem multifunctionality under moderate grazing is associated with high plant but low bacterial diversity in a semi-arid steppe grassland. Plant and Soil, 448, 265-276. https://doi.org/10.1007/s11104-02004430-6

57. Wen, Y.C., Li, H.Y., Lin, Z.A., Zhao, B.Q., Sun, Z.B., Yuan, L. et al. (2020). Long-term fertilization alters soil properties and fungal community composition in fluvo-aquic soil of the North China Plain. Sci Rep, 10, 7198. https://doi.org/10.1038/s41598-020-64227-6

58. Whittaker, R.J. (2006). Island species-energy theory. Journal of Biogeography, 33, 11-12. https://doi.org/10.1111/j.1365-2699.2005.01442.x

59. Xun, W., Yan, R., Ren, Y., Jin, D., Xiong, W., Zhang, G. et al. (2018). Grazing-induced microbiome alterations drive soil organic carbon turnover and productivity in meadow steppe. Microbiome, 6, 170. https://doi.org/10.1186/s40168-018-0544-y

60. Yang, C., Liu, N. \& Zhang, Y. (2019). Soil aggregates regulate the impact of soil bacterial and fungal communities on soil respiration. Geoderma, 337, 444-452.

https://doi.org/10.1016/j.geoderma.2018.10.002

61. Yang, H., Jiang, L., Li, L., Li, A., Wu, M. \& Wan, S. (2012). Diversity-dependent stability under mowing and nutrient addition: evidence from a 7-year grassland experiment. Ecol Lett, 15, 619-626. https://doi.org/10.1111/j.1461-0248.2012.01778.x

62. Yang, L., Maron, J.L. \& Callaway, R.M. (2015). Inhibitory effects of soil biota are ameliorated by high plant diversity. Oecologia, 179, 519-525. https://doi.org/10.1007/s00442-015-3351-1

63. Yang, X., Shen, Y., Chen, J., Guo, Y. \& Zhang, Y. (2018). How do mycorrhizal suppression and plant functional group loss affect plant communities in Inner Mongolia Steppe. Journal of Vegetation Science, 29, 640-650. https://doi.org/10.1111/jvs.12640

64. Yin, Y., Wang, Y., Li, S., Liu, Y., Zhao, W., Ma, Y. et al. (2019). Soil microbial character response to plant community variation after grazing prohibition for 10 years in a Qinghai-Tibetan alpine meadow. 
Figures
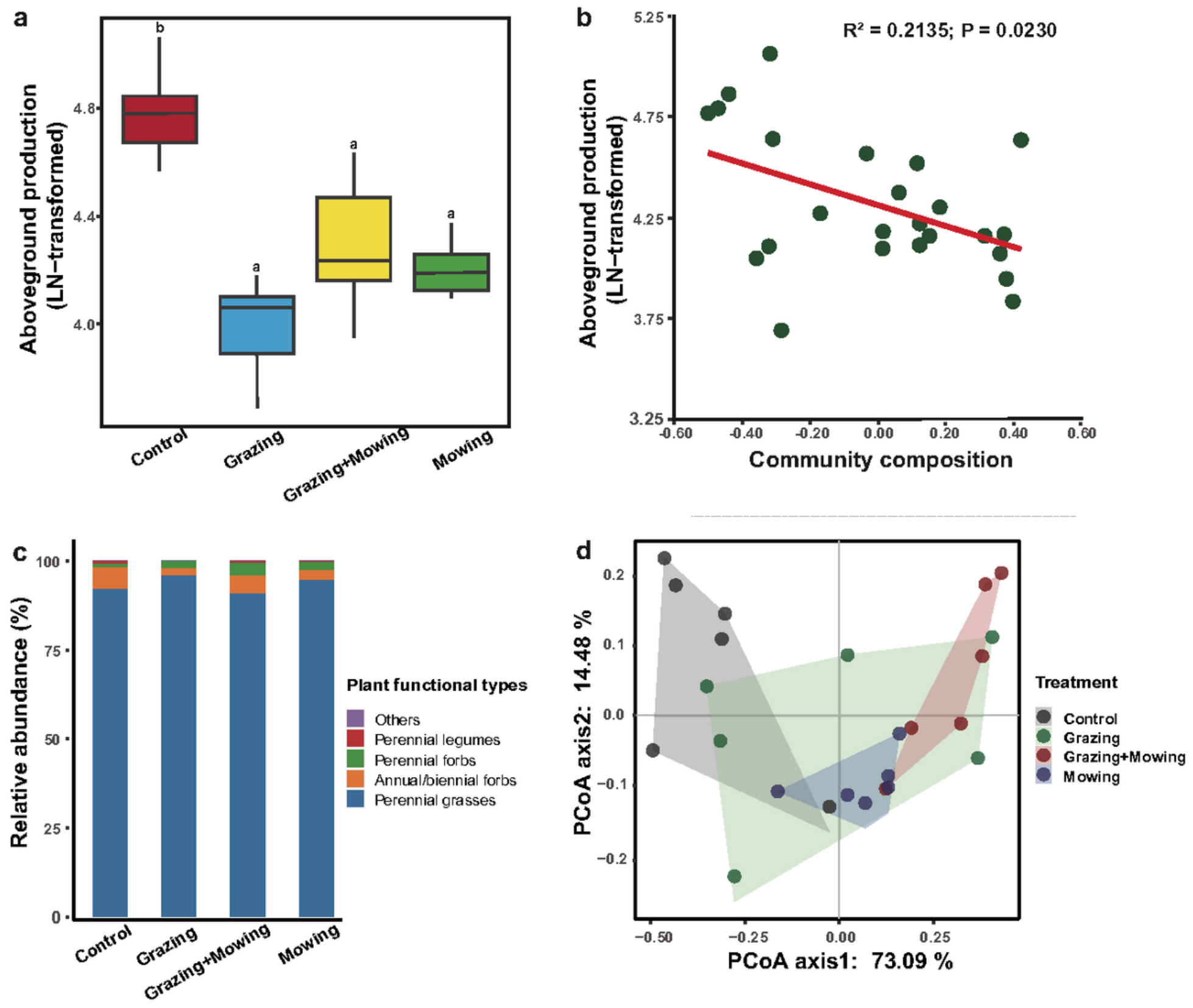

Figure 1

Aboveground production (a), relationships between plant community composition and production (b). Points in Figures (a) and (b) represent plot values, and the box-plot exhibited quartile values for grassland disturbances. (c) The relative abundance of grassland disturbances. (d) Ordination plot derived from principle coordinate analyses of Bray-Curtis distances between plant community composition under grassland disturbances. Points in Figures (a) and (b) represent plot values, and the box-plot exhibited quartile values for grassland disturbances. 
Surface
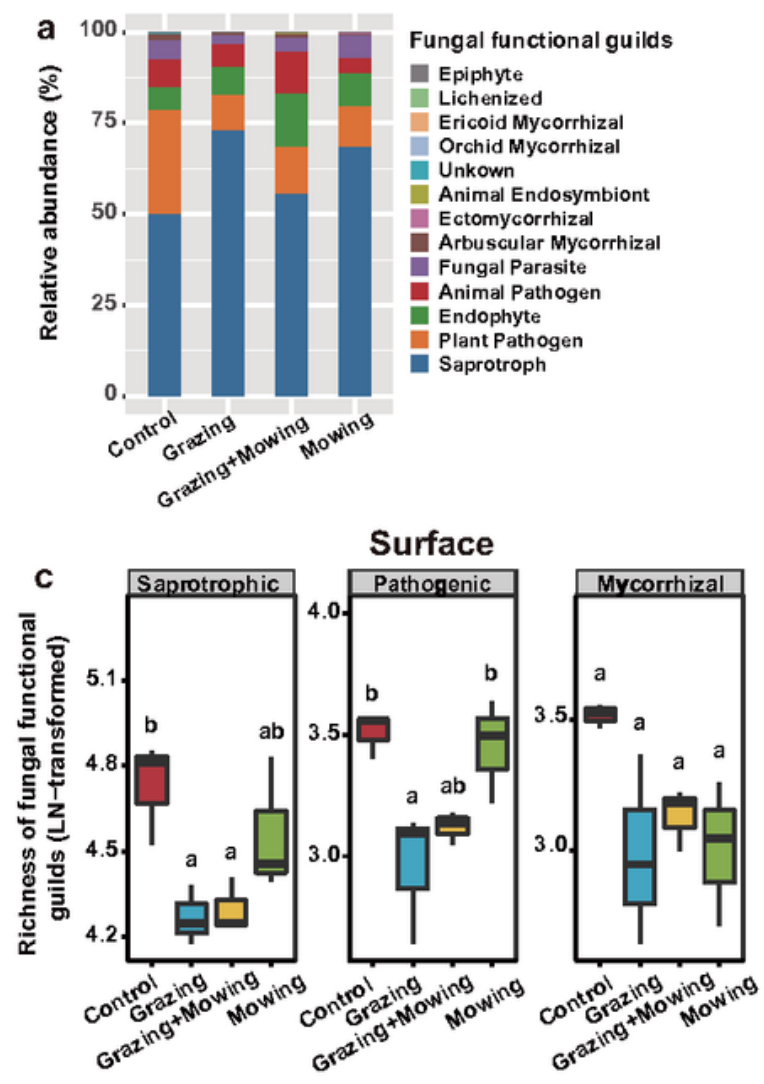

Subsurface
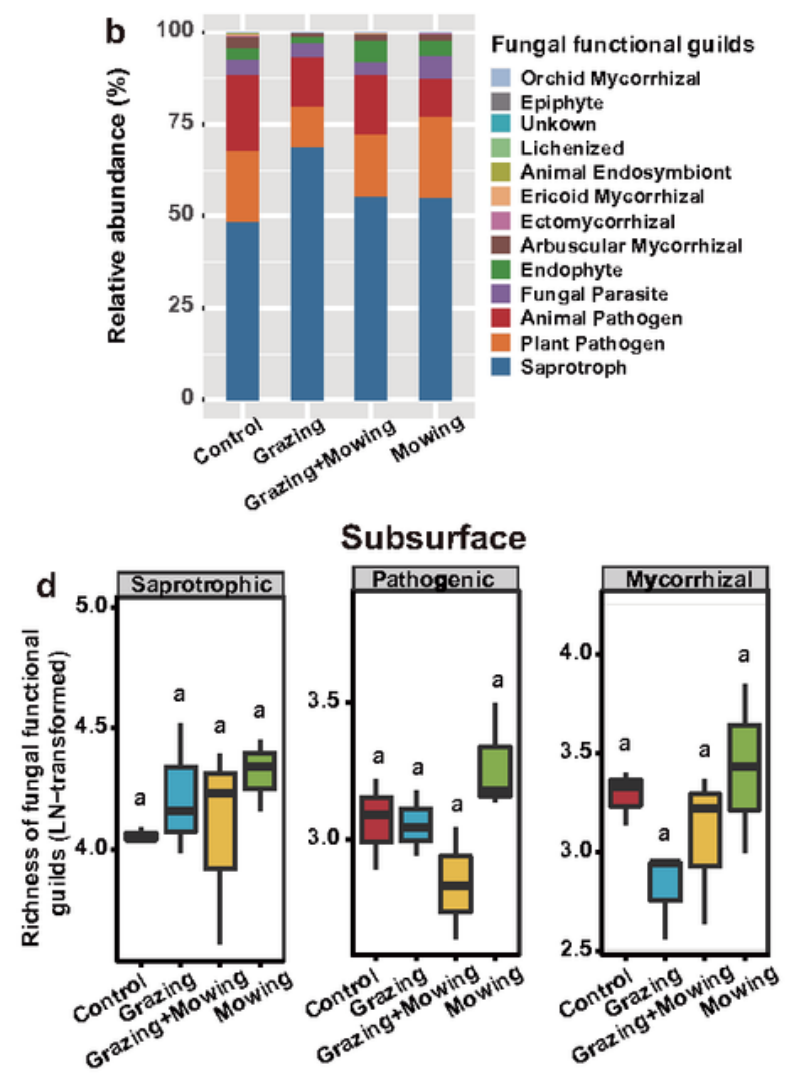
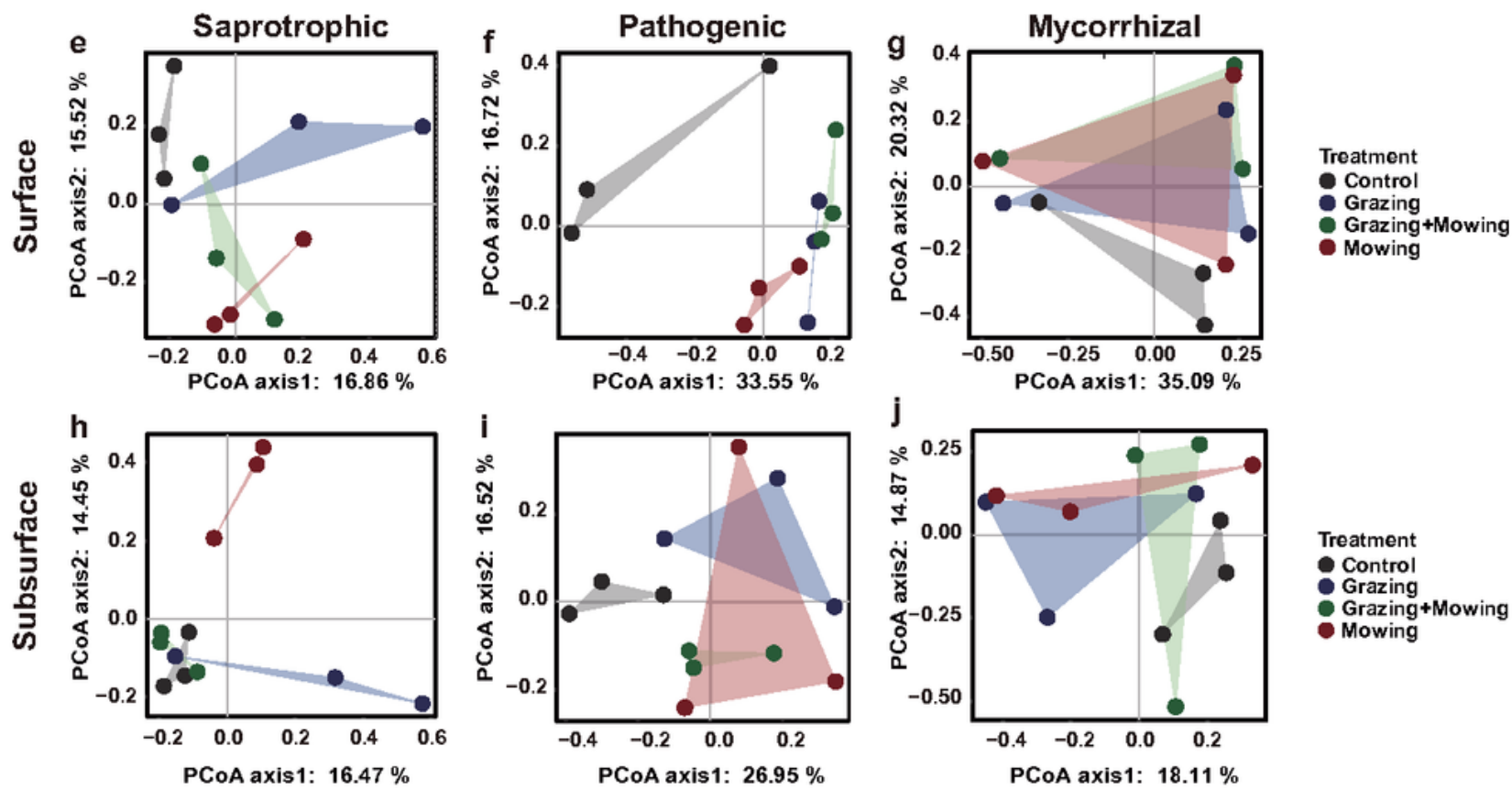

Treatment

- Control

- Grazing

Grazing+Mowing

- Mowing

Figure 2

Relative abundance of functional guilds in (a) surface and (b) subsurface soil. Richness of fungal functional guilds in (c) surface and (d) subsurface soil. Ordination plot derived from principle coordinate analyses of Bray-Curtis distances between fungal functional guilds in $(e, f, g)$ surface and $(h, i, j)$ subsurface soil. 

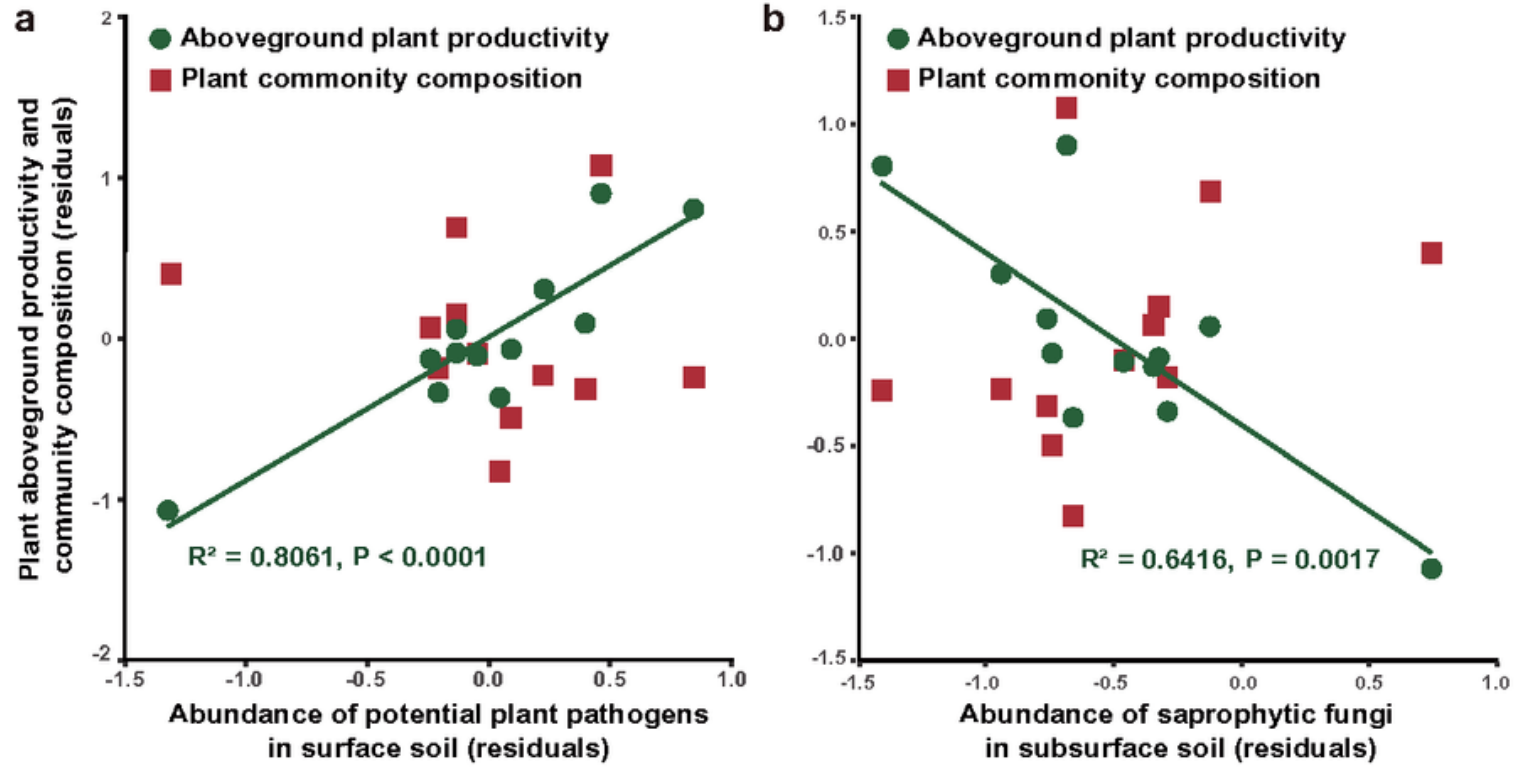

C Plant aboveground productivity

d

\section{Plant community composition}
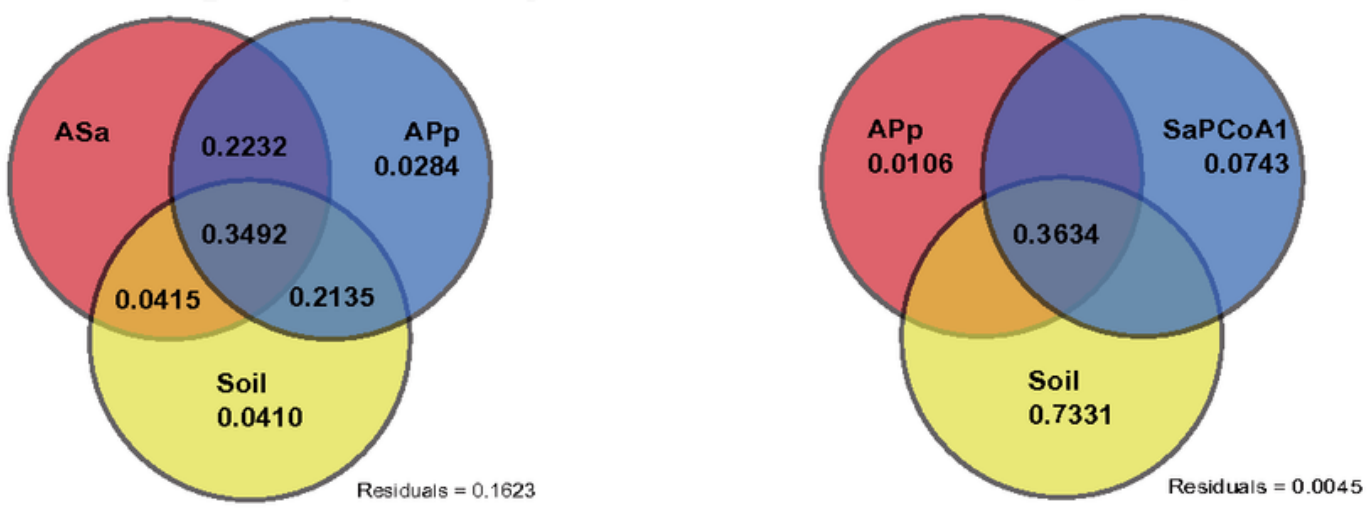

e

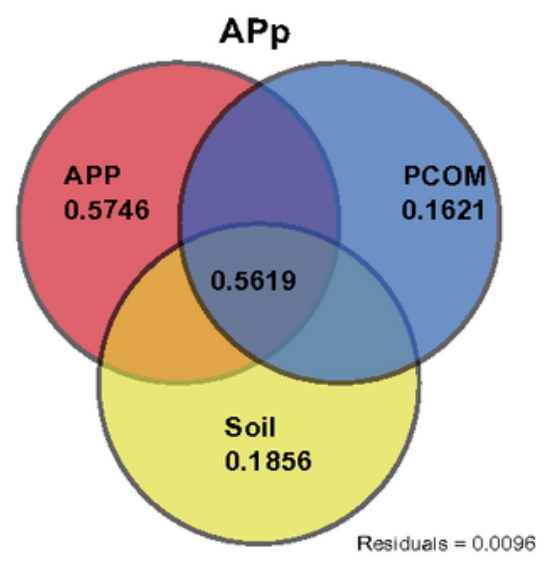

f

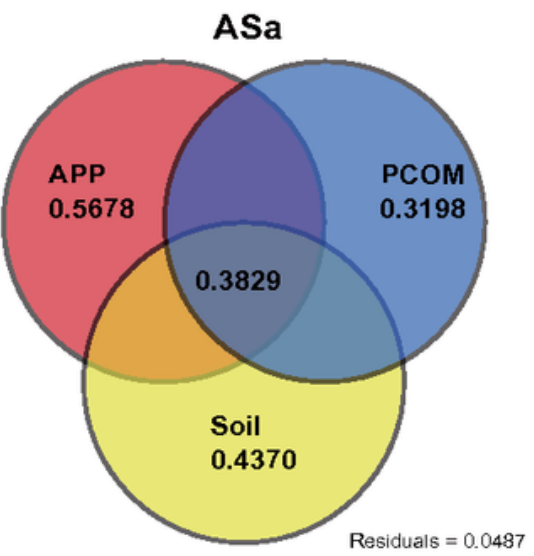

\section{Figure 3}

Relationships between the abundance of potential plant pathogens (APp), saprophytic fungi (ASa), and plant community composition (PCOM), as well as aboveground plant production(APP) based on partial linear regression and variation partitioning analysis in the surface soil. (a) Relationships between the abundance of potential plant pathogens and plant community composition and plant productivity after accounting for the effects of soil biotic and abiotic variables. (b) Relationships between the abundance 
of saprophytic fungi and plant community composition and plant productivity after accounting for the effects of soil biotic and abiotic variables. (c) Venn diagram of the variation partitioning analysis, illustrating the shared and separate effects of APp, ASa and edaphic variables on aboveground plant productivity. (d) Venn diagram of variation partitioning analysis, illustrating the shared and separate effects of APp, SaPCoA1 and edaphic variables on plant community composition, as well as the shared and exclusive effects of plant community composition, aboveground plant productivity, and edaphic variables on (e) APp and (f) SR.My. The solid colored lines in (a) and (b) indicate statistical significance for the relationships. Ovals indicate the interaction of two variables and rectangles indicate the interaction of three variables. 


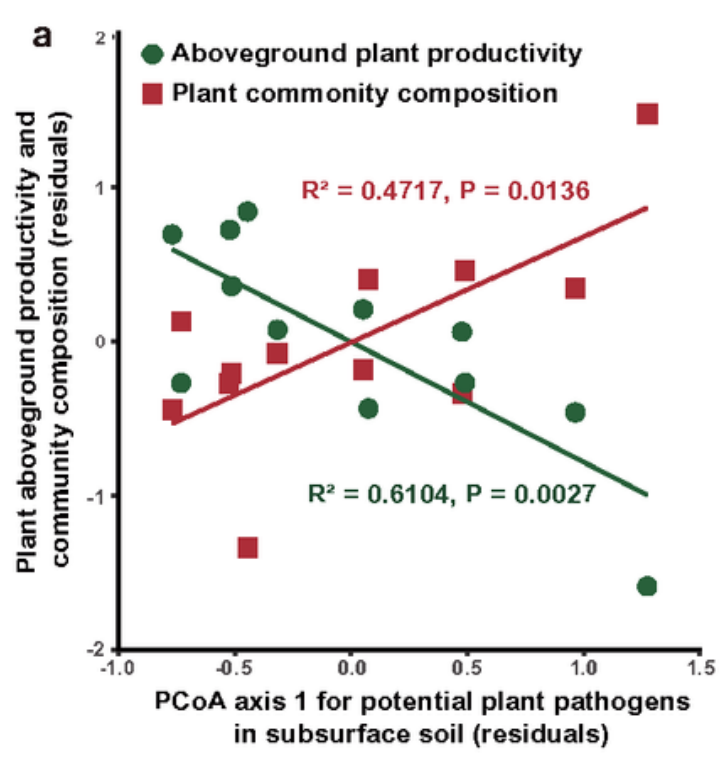

c Plant aboveground productivity

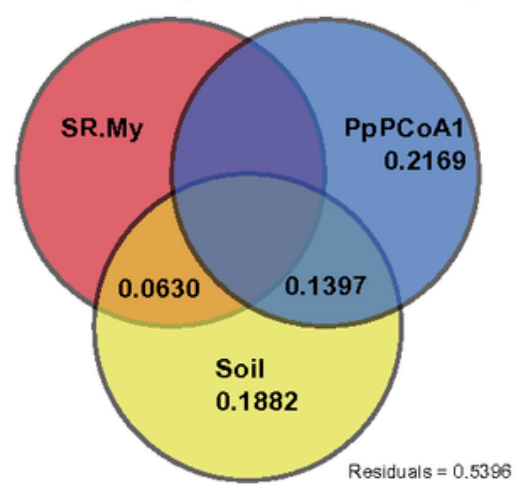

e

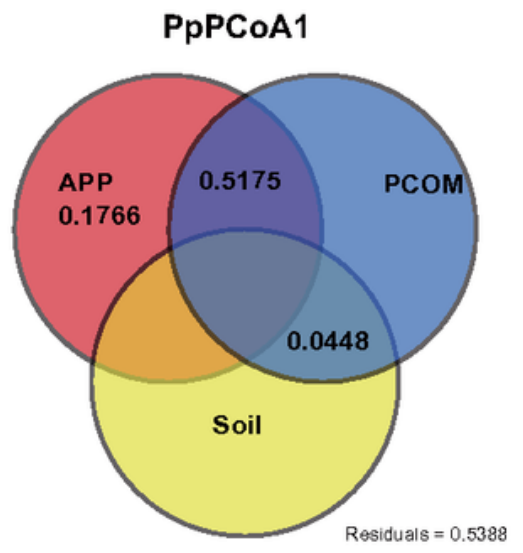

b

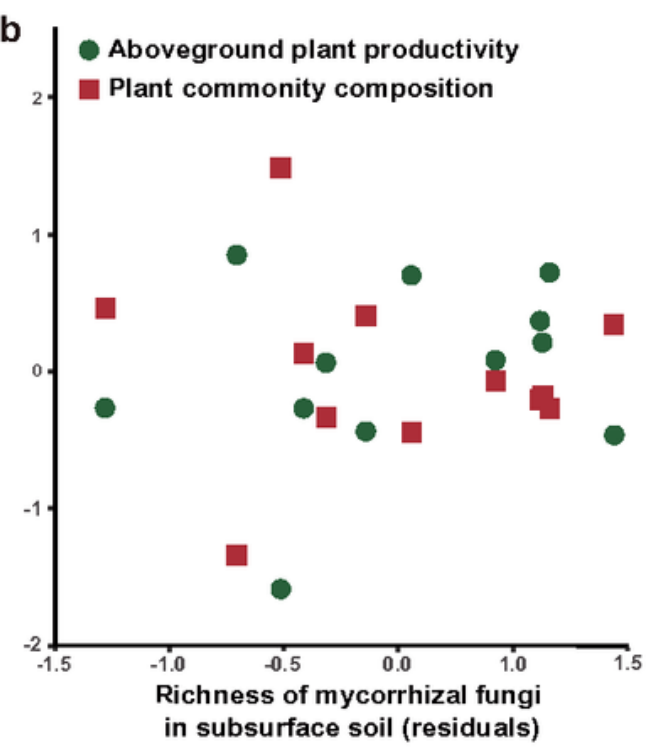

d Plant community composition

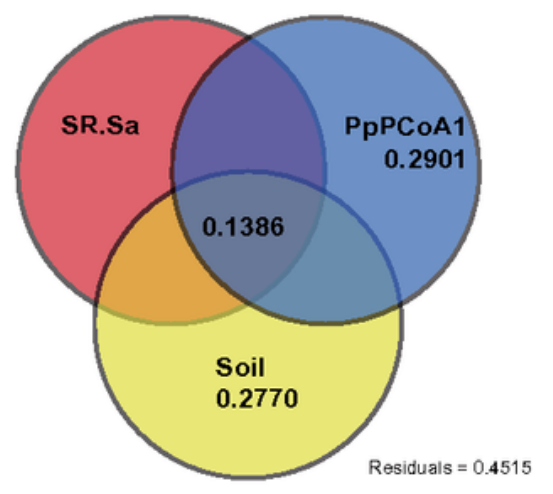

\section{Figure 4}

Relationships between PCoA axis 1 for potential plant pathogens (PpPCoA1), the richness of rhizosphere mycorrhizal fungi (SR.My) and plant community composition (PCOM), as well as production (APP) based on partial linear regression and variation partitioning analyses in the subsurface soil. (a) Relationships between PCoA axis 1 for potential plant pathogens and plant community composition or productivity after accounting for the effects of soil biotic and abiotic variables. (b) Relationships between the richness 
of rhizosphere mycorrhizal fungi and plant community composition or productivity after accounting for the effects of soil biotic and abiotic variables. (c) Venn diagram of the variation partitioning analysis, illustrating the shared and separate effects of PpPCoA1, SR.My and edaphic variables on aboveground plant productivity. (d) Venn diagram of the variation partitioning analysis, illustrating the shared and exclusive effects of PpPCoA1, SR.Sa and edaphic variables on plant community composition. (e) The shared and separate effects of plant community composition, aboveground plant productivity, and edaphic variables on PpPCoA1.The solid colored lines in (a) and (b) indicate statistical significance for the relationships. Ovals indicate the interaction of two variables and rectangles indicate the interaction of three variables. 


\section{a Surface}

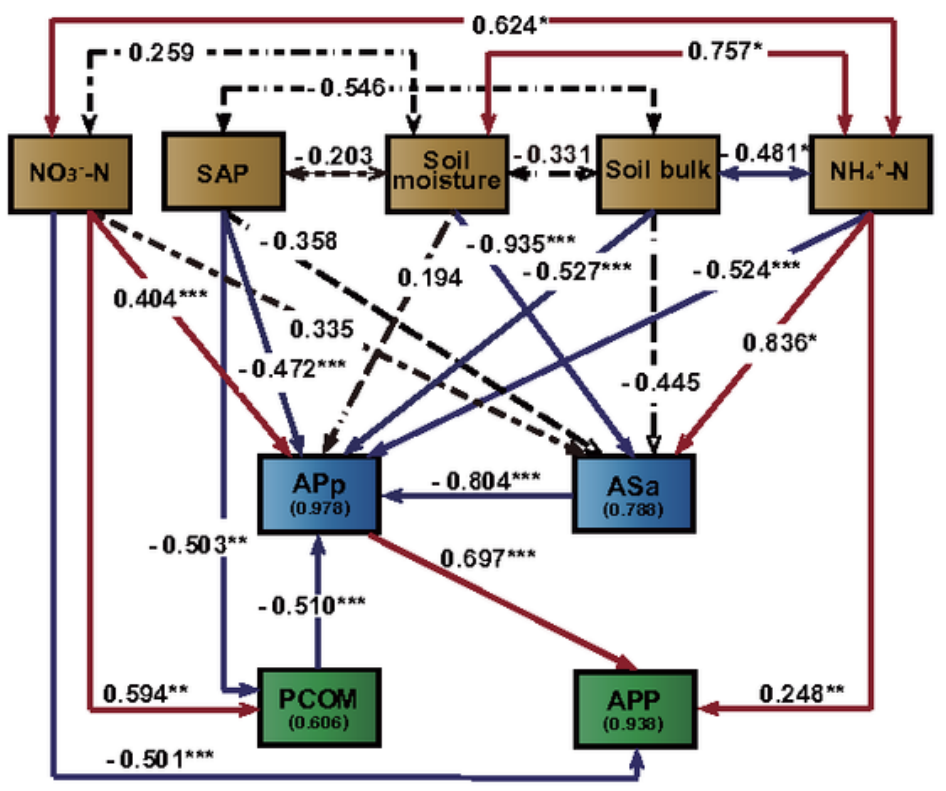

$x^{2}=11.741, \mathrm{P}=0.467, \mathrm{Df}=12 ; \mathrm{RMSEA}=0.000, \mathrm{P}=0.495$

\section{b Subsurface}

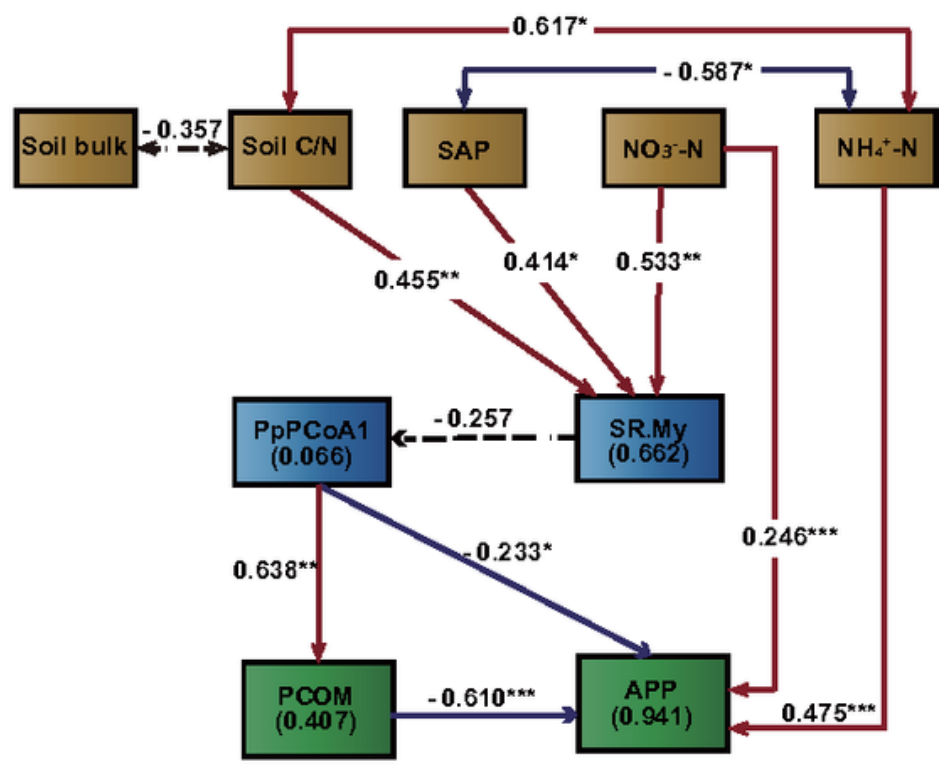

$x^{2}=18.387, \mathrm{P}=0.784, \mathrm{Df}=24 ; \mathrm{RMSEA}=0.000, \mathrm{P}=0.808$

\section{Figure 5}

Direct and indirect effects of edaphic variables on fungal functional guilds and plant indexes. Structural equation models (SEM) are shown in (a) surface and (b) subsurface soil. Numbers adjacent to each arrow are the standardized path coefficient indicating the effect size of the relationship. The width of the arrows is proportional to the strength of path coefficients. R2 denotes the fraction of variance explained. Details for model fitness are presented below each figure. Significance levels are as follows: ${ }^{*}, \mathrm{P}<0.05$; 
$\star \star, P<0.01 ; * \star \star, P<0.001$. Continuous and dashed arrows indicated positive and negative relationships, respectively. PCOM: plant community composition; APP: aboveground plant production; APp: abundance of potential plant pathogens; ASa: abundance of saprophytic fungi; PpPCoA1: PCoA axis 1 for potential plant pathogens; SR.My: richness of mycorrhizal fungi; NO3--N: soil nitrate-nitrogen; NH4+-N: soil ammonium nitrogen; SAP: soil available phosphorous; Soil C/N: Soil C/N ratio.

\section{Supplementary Files}

This is a list of supplementary files associated with this preprint. Click to download.

- Supplementaryfiles.docx 